\title{
Validation study on the geometric isomers from bulbs of Allium fistulosum and their conversion
}

\author{
Joo Tae Hwang, Jin Ah Ryuk, Hye Jin Kim, Dong Ho Jung and Byoung Seob Ko* (i)
}

\begin{abstract}
To discover new standard for the standardization of bulbs of Allium fistulosum (Chongbaek, Korean herbal name), twelve compounds (1-12) were isolated. Among them, a new HPLC/UV analysis method by selecting the five cinnamic acid amides (5-9) and two decursidate isomers (10 and $\mathbf{1 1}$ ), was fully validated. The developed analysis method showed sufficient reproducibility $(<2.58 \%)$ and accuracy (96.00-106.72\%). Moreover, among compounds 5-11, only trans-isomers were verified from all four Chongbaek samples which produced in different regions, and this finding implied that the cis-forms were not originally nature compounds, thus, it led us to verify the conversion processes. The four trans-standard solutions and extracts of Chongbaek were converted to the cis- derivatives after $96 \mathrm{~h}$ of UV (254 nm) light exposure as 78.74\% (6), 82.29\% (8), and 63.99\% (11) in solution and 82.38\% (6), 62.91\% (8), and $61.64 \%$ (11) in extracts. A verified analysis method using new indicators was developed for quality control of Chongbaek, as well as their stability control under UV light exposure. These results might be important for the industrial use of Chongbaek.
\end{abstract}

Keywords: Allium fistulosum, Cinnamic acid amides, HPLC/UV, Validation, Geometric isomer, Conversion

\section{Introduction}

Allium fistulosum is a plant in the Allium family, which includes onions (Allium cepa) and garlic (Allium sati$v u m$ ), and it is commonly called Welsh onion. The dried bulbs (a round root) of A. fistulosum used in this study is called "Chongbaek" in Korean Oriental medicine and it has long been used in one of the compositional herb with several prescriptions for treatment of colds, indigestion and even dermatitis $[1,2]$.

A typical component of Chongbaek is allicin, which has a strong spicy flavor, and this flavor can be degraded by inactivation of the alliin within the plant by an alliinase enzyme [3]. Allicin has been reported to have antibacterial, anticancer, blood sugar and blood pressure reductive, arteriosclerosis preventative effects [4-6]. Apart

\footnotetext{
*Correspondence: bsko@kiom.re.kr

Herbal Medicine Research Division, Korea Institute of Oriental Medicine, Daejeon 34054, Republic of Korea
}

from the various activities of allicin noted above, allicin is unstable in extraction processes due to its high volatility [7]. In addition, in the case of Chongbaek, which are used for medicinal purposes, allicin's original pharmacological effects cannot be predicted, mainly because it is not consumed raw but is usually boiled or shredded into small pieces.

The other major components reported in A. fistulosum include phenolic acids such as $p$-coumaric and ferulic acid and flavonoids such as rutin and quercitrin $[1,8$, 9]. However, these compounds, including allicin, are not characteristic of Chongbaek because they are also found in many other Allium families. Recently, several new sulfur-containing compounds were reported [3], and various furostanol saponins were isolated from Chongbaek [10]. Cinnamic acid amides were also reported, and they show various activities, such as antibacterial activity and cytotoxicity [11-13]. As such, selecting one of the newly isolated compounds to use as a standard for analysis 
may allow higher specificity in the quality control of these materials. In particular, traditional medicines use a number of mixed-use prescriptions that contain various medicinal materials. At this time, standardizing complex prescriptions would not be possible if the contents and proportions of the raw materials used could not be accurately determined.

For this reason, the purpose of this study was to explore new, more stable, bioactive compounds that can be used for the standardization and industrialization of the selected herbal medicine. The following report describes the identification of twelve compounds, from $70 \%$ ethanol extract of Chongbaek (Fig. 1) and the development of a rapid and accurate HPLC analysis method for the selected compounds as standards. In addition, the standard contents of Chongbaek samples which produced in four different regions were compared by using the developed analysis method for the quality control of Chongbaek.<smiles>O=C(CO)c1ccccc1O</smiles>

1<smiles>[R]c1cc(C=CC(=O)NC(=O)COc2ccc(O)c([R2])c2)ccc1O</smiles><smiles>[R1][CH][R1]</smiles><smiles>COc1cc(C=CC(=O)OC[C@@H](O)c2ccc(O)cc2)ccc1O</smiles>

10<smiles>COc1coc2ccccc12</smiles>

2<smiles>c1ccc2c(c1)CCO2</smiles>

3<smiles>CCOc1ccccc1C(O)CO</smiles>

4<smiles>[R2]c1cc(/C=C/C(=O)NCCc2ccc(O)c([R])c2)ccc1O</smiles>

\begin{tabular}{ccc} 
& $\mathbf{R}_{\mathbf{1}}$ & $\mathbf{R}_{\mathbf{2}}$ \\
\cline { 2 - 3 } $\mathbf{6}$ & $\mathrm{OCH}_{3}$ & $\mathrm{H}$ \\
$\mathbf{8}$ & $\mathrm{OCH}_{3}$ & $\mathrm{OCH}_{3}$
\end{tabular}<smiles>COc1cc(/C=C/C(=O)OC[C@H](O)c2ccc(O)cc2)ccc1O</smiles>

11<smiles>OC[C@H](O)c1ccc(O)cc1</smiles>

Fig. 1 Chemical structures of the compounds isolated from $70 \%$ ethanol extract of Chongbaek 


\section{Materials and methods}

\section{General procedures}

All analytical-grade solvents, namely, methanol $(\mathrm{MeOH})$, acetonitrile $(\mathrm{ACN})$ and water $\left(\mathrm{H}_{2} \mathrm{O}\right)$, were obtained from J. T. Baker (Phillipsburg, NJ, USA). Analytical-grade formic acid buffer was purchased from Sigma-Aldrich (St. Louis, MO, USA). Ethyl alcohol (EtOH), $n$-hexane (HEX), ethyl acetate (EtOAc), and $n$-butanol $(\mathrm{BuOH})$ were extrapure grade and were purchased from Dae-Jung Chemicals and Metals (Gyeonggi-do, Korea). To separate and isolate the compounds, open column chromatography was conducted using silica gel (Kieselgel 60, 70-230 mesh, Merck), and a recycled preparative system based on LC-Forte/R model (YMC, Tokyo, Japan) was used. The structures of the isolated compounds were characterized by ${ }^{1} \mathrm{H}$ NMR, ${ }^{13} \mathrm{C}$ NMR, ${ }^{1} \mathrm{H}-{ }^{1} \mathrm{H}$ COSY, HMBC, and HMQC spectrometry as well as ESI-MS. A $600 \mathrm{MHz}$ NMR, JNM-ECA600 (Jeol, Tokyo, Japan) was used for recording the spectra of all compounds. DMSO-d6 and $\mathrm{CD}_{3} \mathrm{OH}$ were used as solvents, and TMS was used as an internal standard. All the chemical shifts are presented in ppm. MS data were obtained with JEOL JMS-700 (Jeol, Tokyo, Japan) and Bruker maXis 4G (Bruker, WI, USA) mass spectrometers in positive and negative ion modes. The HPLC separations were conducted with a Shimadzu LC-20A Prominence Series system (Shimadzu corporation, Kyoto, Japan) with a quaternary pump (LC-20AD), a vacuum degasser (DGU-20A3R), an autosampler (SIL20A), a column oven (CTO-20A) and a photodiode-array detector (SPD-M20A). Chromatographic data were processed by LabSolutions Multi PDA software.

\section{Sample collection}

Dried raw samples for separation and isolation of the target compounds were purchased in January 2018. The samples were produced in Gyeongsan, Korea, for use as standard medicinal products. To confirm the identity of the samples, an expert inspection committee from the Korea Institute of Oriental Medicine was consulted, and voucher specimens of all samples were kept in the KIOM.

Moreover, another three samples for standardization of the raw materials were acquired from Jindo (in July 2019), Kimpo (in July 2019), Yeongcheon (in November 2019), and Mu-ahn (in October 2019) from Korea, and all samples for analysis were likewise identified by KIOM's experts and kept as medicinal standards by KIOM.

\section{Separation and isolation procedures}

The Chongbaek sample $(8 \mathrm{~kg})$ were immersed in $40 \mathrm{~L}$ (approximately 5 times the sample weight) of $70 \% \mathrm{EtOH}$, and the solid was extracted three times at $80{ }^{\circ} \mathrm{C}$ for $24 \mathrm{~h}$ each. The combined sample extract was concentrated under reduced pressure to afford $1.2 \mathrm{~kg}$ of the $70 \%$ EtOH extract. Next, $800 \mathrm{~g}$ of the $70 \% \mathrm{EtOH}$ extract was suspended in $\mathrm{H}_{2} \mathrm{O}(1.5 \mathrm{~L})$ and partitioned sequentially into $n$-hexane $(3 \mathrm{~L} \times 4)$, EtOAc $(3 \mathrm{~L} \times 4)$, and $n$ - $\mathrm{BuOH}$ $(3 \mathrm{~L} \times 3)$ based on polarity. The four solvent fractions (n-hexane, EtOAc, n- $\mathrm{BuOH}$, and $\mathrm{H}_{2} \mathrm{O}$ ) were all concentrated under reduced pressure to remove the solvent, and the EtOAc fraction (16.66 g) was chromatographed on a silica gel column $(15 \times 80 \mathrm{~cm}, 200-400$ mesh $)$ and eluted with a gradient of $n$-hexane and EtOAc (n-hexane:EtOAc $=100: 0$ to 0:100, $v / v$ ). Among the six fractions from the EtOAc fraction (fr. E1 fr. E6), fr. E2 $(11.2 \mathrm{~g})$ was fractionated by semipreparative HPLC at a flow rate of $20 \mathrm{~mL} / \mathrm{min}$, detection at 210 and $235 \mathrm{~nm}$ $\mathrm{UV}$, and a gradient system containing $\mathrm{H}_{2} \mathrm{O}$ and $\mathrm{ACN}$ $(91: 9-85: 15, v / v)$ on a YMC Triat C18 column $(5 \mu m$, $150 \times 21.20 \mathrm{~mm}$ i.d.). The separation of fr. E2, afforded fr. E21 to E26, and from these fractions, compounds 1 (6.5 mg), 2 (38.8 mg), 3 (49.8 mg), and 4 (21.8 mg) were obtained.

Compounds 5 (84.9 mg), 10 (5.4 mg), and 11 (31.3 mg) were isolated from fr. E3 (525.5 $\mathrm{mg}$ ) and compound $\mathbf{1 2}$ (37.6 mg) was isolated from fr. E4 (224.8 mg) by using semipreparative HPLC with a YMC Triat C18 column (5 $\mu \mathrm{m}, 150 \times 21.20 \mathrm{~mm}$ i.d.). The chromatographic conditions were a flow rate of $20 \mathrm{~mL} / \mathrm{min}$, UV detection at 254 and $320 \mathrm{~nm}$, and a gradient solvent system with $\mathrm{H}_{2} \mathrm{O}: \mathrm{ACN}=87: 13-85: 15, v / v$.

Fraction E5 (609.9 mg) was also fractionated by semipreparative HPLC (YMC Triat C18, $5 \mu \mathrm{m}$, $150 \times 21.20 \mathrm{~mm}$ i.d., flow rate of $20 \mathrm{~mL} / \mathrm{min}, \mathrm{UV}$ detection at 254 and $320 \mathrm{~nm}$ ) and afforded five fractions (E51 to E55) with a gradient solvent system $\left(\mathrm{H}_{2} \mathrm{O}: \mathrm{ACN}=87: 13-85: 15, v / v\right)$. Among them, fr. E52 (110.8 mg) was further separated under the same conditions as fr. E5, and fractions E521 to E525 were collected. Fraction E521 (20.8 mg) afforded compounds 6 (4.8 mg) and $7(12.8 \mathrm{mg})$ from semipreparative HPLC (YMC Triat C18, $5 \mu \mathrm{m}, 150 \times 21.20 \mathrm{~mm}$ i.d., flow rate of $15 \mathrm{~mL} / \mathrm{min}$, $\mathrm{UV}$ detection at 254 and $320 \mathrm{~nm}, \mathrm{H}_{2} \mathrm{O}: \mathrm{ACN}=87: 13-$ 85:15, v/v). Compounds 8 (10.2 $\mathrm{mg})$ and 9 (9.6 mg) were isolated from fraction E $523(60.8 \mathrm{mg})$ by using the same conditions as were used to obtain compounds $\mathbf{6}$ and 7 .

The purity of each of the isolated compounds was confirmed by HPLC analysis, and all were at least 95\% pure.

\section{2-Hydroxy-1-(2-hydroxyphenyl)ethanone (1)}

Brown oil. ESI-MS ion peaks at $m / z 153.0[\mathrm{M}+\mathrm{H}]^{+}$and $150.9[\mathrm{M}-\mathrm{H}]^{-} .{ }^{1} \mathrm{H}$ NMR data in $\mathrm{CD}_{3} \mathrm{OD}(600 \mathrm{MHz}): \delta_{\mathrm{H}}$ $7.83(2 \mathrm{H}, d, J=10.2, \mathrm{H}-2$ and $\mathrm{H}-4), 6.83(2 \mathrm{H}, d, J=10.2$, $\mathrm{H}-3$ and $\mathrm{H}-5), 4.79$ (2H, s, H-8). ${ }^{13} \mathrm{C}$ NMR data in $\mathrm{CD}_{3} \mathrm{OD}$ $(600 \mathrm{MHz}): \delta_{\mathrm{C}} 198.7(\mathrm{C}-7), 164.3(\mathrm{C}-5), 131.4(\mathrm{C}-2$ and C-4), 127.5 (C-1), 116.6 (C-3 and C-5), 66.0 (C-8). 


\section{3-Methoxy-coumaran (2)}

Yellow-brown oil. ESI-MS ion peaks at $\mathrm{m} / z 151.2$ $[\mathrm{M}+\mathrm{H}]^{+}$and $150.9[\mathrm{M}-\mathrm{H}]^{-} \cdot{ }^{1} \mathrm{H}$ NMR data in $\mathrm{CD}_{3} \mathrm{OD}$ $(600 \mathrm{MHz}): \delta_{\mathrm{H}} 7.12(2 \mathrm{H}, d, J=9.6, \mathrm{H}-2$ and $\mathrm{H}-4), 6.77$ $(2 \mathrm{H}, d, J=9.6, \mathrm{H}-3$ and $\mathrm{H}-5), 4.16(1 \mathrm{H}, d d, J=9.6,4.8$, $\mathrm{H}-8), 3.62(1 \mathrm{H}, d d, J=13.8,4.8, \mathrm{H}-7 \alpha), 3.50(1 \mathrm{H}, d d$, $J=13.8,4.8, \mathrm{H}-7 \beta), 3.22\left(3 \mathrm{H}, \mathrm{s}, 8-\mathrm{OCH}_{3}\right) .{ }^{13} \mathrm{C} \mathrm{NMR}$ data in $\mathrm{CD}_{3} \mathrm{OD}(600 \mathrm{MHz}): \delta_{\mathrm{C}} 158.5(\mathrm{C}-7), 131.0(\mathrm{C}-1)$, 129.4 (C-2 and C-4), 116.3 (C-3 and C-5), 86.1 (C-8), $67.9(\mathrm{C}-7), 57.0\left(8-\mathrm{OCH}_{3}\right)$.

\section{Coumaran (3)}

Yellow oil. ESI-MS ion peaks at $m / z$ 121.1 $[\mathrm{M}+\mathrm{H}]^{+}$ and $119.1[\mathrm{M}-\mathrm{H}]^{-}$. ${ }^{1} \mathrm{H}$ NMR data in $\mathrm{CD}_{3} \mathrm{OD}$ $(600 \mathrm{MHz}): \delta_{\mathrm{H}} 7.02(2 \mathrm{H}, d, J=10.2, \mathrm{H}-2$ and $\mathrm{H}-4), 6.71$ $(2 \mathrm{H}, d, J=10.2, \mathrm{H}-3$ and $\mathrm{H}-5), 3.68(2 \mathrm{H}, t, J=8.4, \mathrm{H}-7 \alpha$ and $\mathrm{H}-7 \beta), 2.71(2 \mathrm{H}, t, J=8.4, \mathrm{H}-8 \alpha$ and $\mathrm{H}-8 \beta) .{ }^{13} \mathrm{C}$ NMR data in $\mathrm{CD}_{3} \mathrm{OD}(600 \mathrm{MHz}): \delta_{\mathrm{C}} 155.4(\mathrm{C}-6), 129.7$ (C-1), 129.6 (C-2 and C-4), 114.8 (C-3 and C-5), 63.3 (C-7), 38.1 (C-8).

\section{1-(2-Ethoxyphenyl)-1,2-ethanediol (4)}

Brown oil. ESI-MS ion peaks at $m / z 183.1[\mathrm{M}+\mathrm{H}]^{+}$ and $181.1[\mathrm{M}-\mathrm{H}]^{-} \cdot{ }^{1} \mathrm{H}$ NMR data in $\mathrm{CD}_{3} \mathrm{OD}$ $(600 \mathrm{MHz}): \delta_{\mathrm{H}} 7.13(2 \mathrm{H}, d, J=10.2, \mathrm{H}-2$ and $\mathrm{H}-4), 6.76$ $(2 \mathrm{H}, d, J=10.2, \mathrm{H}-3$ and $\mathrm{H}-5), 4.27(1 \mathrm{H}, d d, J=10.2$, 4.8, H-7), $3.62(1 \mathrm{H}, d d, J=13.8,9.6, \mathrm{H}-8 \alpha), 3.49(1 \mathrm{H}$, $d d, J=13.8,9.6, \mathrm{H}-8 \beta), 3.39(2 \mathrm{H}, m, \mathrm{H}-9 \alpha$ and $\mathrm{H}-9 \beta)$, $1.17\left(3 \mathrm{H}, t, J=8.4,9-\mathrm{CH}_{3}\right) .{ }^{13} \mathrm{C} \mathrm{NMR}$ data in $\mathrm{CD}_{3} \mathrm{OD}$ (600 MHz): $\delta_{\mathrm{C}} 158.4(\mathrm{C}-6), 131.7(\mathrm{C}-1), 129.3$ (C-2 and C-4), 116.3 (C-3 and C-5), 84.2 (C-7), 68.0 (C-8), 65.3 (C-9), $15.7\left(9-\mathrm{CH}_{3}\right)$.

\section{N-Trans-coumaroyl tyramine (5)}

Bright-yellow powder. ESI-MS ion peaks at $m / z 284.2$ $[\mathrm{M}+\mathrm{H}]^{+}$and $281.9[\mathrm{M}-\mathrm{H}]^{-} .{ }^{1} \mathrm{H}$ NMR data in DMSO$d 6(600 \mathrm{MHz}): \delta_{\mathrm{H}} 7.34(2 \mathrm{H}, d, J=8.4, \mathrm{H}-2$ and $\mathrm{H}-6)$, $7.29(1 \mathrm{H}, d, J=16.2, \mathrm{H}-7), 6.97\left(2 \mathrm{H}, d, J=8.4, \mathrm{H}-2^{\prime}\right.$ and $\left.\mathrm{H}-6^{\prime}\right), 6.75(2 \mathrm{H}, d, J=8.4, \mathrm{H}-3$ and $\mathrm{H}-5), 6.65(2 \mathrm{H}$, $d, J=8.4, \mathrm{H}-3^{\prime}$ and $\left.\mathrm{H}-5^{\prime}\right), 6.37(1 \mathrm{H}, d, J=16.2, \mathrm{H}-8)$, $3.30(2 \mathrm{H}, d d, J=13.8,6.6, \mathrm{H}-8 \alpha$ and $\mathrm{H}-8 \beta), 2.62(2 \mathrm{H}$, $t, J=7.2, \mathrm{H}-9 \alpha$ and $\mathrm{H}-9 \beta) .{ }^{13} \mathrm{C}$ NMR data in DMSO- $d 6$ $(600 \mathrm{MHz}): \delta_{\mathrm{C}} 165.9$ (C-9), 159.3 (C-4), 156.1 (C-4'), 139.1 (C-7), 130.1 (C-1), 130.0 (C-2 and C-6), 129.7 (C-2' and C-6'), $126.5\left(\mathrm{C}-1^{\prime}\right), 119.3(\mathrm{C}-8), 116.3(\mathrm{C}-3$ and $\mathrm{C}-5), 115.7\left(\mathrm{C}-3^{\prime}\right.$ and $\left.\mathrm{C}-5^{\prime}\right), 41.2\left(\mathrm{C}-7^{\prime}\right), 35.0\left(\mathrm{C}-8^{\prime}\right)$.

\section{$\mathrm{N}$-Cis-feruloyltyramine (6)}

Yellowish powder. ESI-MS ion peaks at $m / z 314.1$ $[\mathrm{M}+\mathrm{H}]^{+}$and $312.1[\mathrm{M}-\mathrm{H}]^{-} \cdot{ }^{1} \mathrm{H}$ NMR data in $\mathrm{CD}_{3} \mathrm{OD}$ $(600 \mathrm{MHz}): \delta_{\mathrm{H}} 7.33(1 \mathrm{H}, d, J=1.8, \mathrm{H}-2), 6.97(2 \mathrm{H}, d$, $J=8.4, \mathrm{H}-2^{\prime}$ and $\left.\mathrm{H}-6^{\prime}\right), 6.90(1 \mathrm{H}, d d, J=7.8,1.8, \mathrm{H}-6)$,
$6.71(1 \mathrm{H}, d, J=8.4, \mathrm{H}-5), 6.66\left(2 \mathrm{H}, d, J=8.4, \mathrm{H}-3^{\prime}\right.$ and $\left.\mathrm{H}-5^{\prime}\right), 6.59(1 \mathrm{H}, d, J=12.6, \mathrm{H}-7), 5.79(1 \mathrm{H}, d, J=12.6$, $\mathrm{H}-8), 3.81\left(3 \mathrm{H}, \mathrm{s}, 3-\mathrm{OCH}_{3}\right), 3.37\left(2 \mathrm{H}, m, \mathrm{H}-7 \alpha^{\prime}\right.$ and $\left.\mathrm{H}-7 \beta^{\prime}\right), 2.67\left(2 \mathrm{H}, m, \mathrm{H}-8 \alpha^{\prime}\right.$ and $\left.\mathrm{H}-8 \beta^{\prime}\right) .{ }^{13} \mathrm{C}$ NMR data in $\mathrm{CD}_{3} \mathrm{OD}(600 \mathrm{MHz}): \delta_{\mathrm{C}} 196.0(\mathrm{C}-9), 155.5\left(\mathrm{C}-4^{\prime}\right)$, 147.3 (C-3), 147.2 (C-4), 137.0 (C-7), 129.8 (C-1'), 129.3 (C-2' and C-6'), 127.2 (C-1), 123.5 (C-5), 120.3 (C-8), $114.9\left(\mathrm{C}-3^{\prime}\right.$ and $\left.\mathrm{C}-5^{\prime}\right), 114.5(\mathrm{C}-6), 112.6(\mathrm{C}-2), 55.0$ $\left(3-\mathrm{OCH}_{3}\right), 41.0\left(\mathrm{C}-7^{\prime}\right), 34.2\left(\mathrm{C}-8^{\prime}\right)$.

\section{N-Trans-feruloyltyramine (7)}

Brown powder. ESI-MS ion peaks at $m / z 314.2[\mathrm{M}+\mathrm{H}]^{+}$ and $312.0[\mathrm{M}-\mathrm{H}]^{-} .{ }^{1} \mathrm{H} \mathrm{NMR}$ data in $\mathrm{CD}_{3} \mathrm{OD}(600 \mathrm{MHz})$ : $\delta_{\mathrm{H}} 7.41(1 \mathrm{H}, d, J=15.6, \mathrm{H}-7), 7.09(1 \mathrm{H}, d, J=1.8, \mathrm{H}-2)$, $7.03\left(2 \mathrm{H}, d, J=8.4, \mathrm{H}-2^{\prime}\right.$ and $\left.\mathrm{H}-6^{\prime}\right), 7.00(1 \mathrm{H}, d d, J=8.4$, $1.8, \mathrm{H}-6), 6.77(1 \mathrm{H}, d, J=7.8, \mathrm{H}-5), 6.69(2 \mathrm{H}, d, J=9.0$, $\mathrm{H}-3^{\prime}$ and $\left.\mathrm{H}-5^{\prime}\right), 6.38(1 \mathrm{H}, d, J=15.6, \mathrm{H}-8), 3.86(3 \mathrm{H}, \mathrm{s}$, $\left.3-\mathrm{OCH}_{3}\right), 3.44\left(2 \mathrm{H}, t, J=7.2, \mathrm{H}-7 \alpha^{\prime}\right.$ and $\left.\mathrm{H}-7 \beta^{\prime}\right), 2.71(2 \mathrm{H}$, $t, J=7.2, \mathrm{H}-8 \alpha^{\prime}$ and $\left.\mathrm{H}-8 \beta^{\prime}\right) .{ }^{13} \mathrm{C} \mathrm{NMR}$ data in $\mathrm{CD}_{3} \mathrm{OD}$ $(600 \mathrm{MHz}): \delta_{\mathrm{C}} 197.8$ (C-9), $155.5\left(\mathrm{C}-4^{\prime}\right), 148.4(\mathrm{C}-4)$, 147.9 (C-3), 140.7 (C-7), $130.0\left(\mathrm{C}-1^{\prime}\right), 129.4\left(\mathrm{C}-2^{\prime}\right.$ and C-6'), 126.9 (C-1), 121.9 (C-5), 117.5 (C-8), 115.2 (C-6), $115.0\left(\mathrm{C}-3^{\prime}\right.$ and $\left.\mathrm{C}-5^{\prime}\right), 110.2(\mathrm{C}-2), 55.1\left(3-\mathrm{OCH}_{3}\right), 41.3$ $\left(\mathrm{C}-7^{\prime}\right), 34.5\left(\mathrm{C}-8^{\prime}\right)$.

\section{N-Cis-feruloyl-3'-methoxytyramine (8)}

Brown powder. ESI-MS ion peaks at $m / z 344.2[\mathrm{M}+\mathrm{H}]^{+}$ and $342.0[\mathrm{M}-\mathrm{H}]^{-} .{ }^{1} \mathrm{H} \mathrm{NMR}$ data in $\mathrm{CD}_{3} \mathrm{OD}(600 \mathrm{MHz})$ : $\delta_{\mathrm{H}} 7.33(1 \mathrm{H}, d, J=1.8, \mathrm{H}-2), 6.90(1 \mathrm{H}, d d, J=7.8,1.8$, $\mathrm{H}-6), 6.74\left(1 \mathrm{H}, d, J=1.8, \mathrm{H}-2^{\prime}\right), 6.70(1 \mathrm{H}, d, J=7.8$, $\mathrm{H}-5), 6.67\left(1 \mathrm{H}, d, J=7.8, \mathrm{H}-5^{\prime}\right), 6.58\left(2 \mathrm{H}, m, \mathrm{H}-6^{\prime}\right.$ and $\mathrm{H}-7), 5.79(1 \mathrm{H}, d, J=12.6, \mathrm{H}-8), 3.80\left(3 \mathrm{H}, \mathrm{s}, 3-\mathrm{OCH}_{3}\right)$, $3.76\left(3 \mathrm{H}, \mathrm{s}, 3^{\prime}-\mathrm{OCH}_{3}\right) 3.40\left(2 \mathrm{H}, t, J=7.2, \mathrm{H}-7 \alpha^{\prime}\right.$ and $\left.\mathrm{H}-7 \beta^{\prime}\right), 2.69\left(2 \mathrm{H}, t, J=7.2, \mathrm{H}-8 \alpha^{\prime}\right.$ and $\left.\mathrm{H}-8 \beta^{\prime}\right) .{ }^{13} \mathrm{C} \mathrm{NMR}$ data in $\mathrm{CD}_{3} \mathrm{OD}(600 \mathrm{MHz}): \delta_{\mathrm{C}} 169.0(\mathrm{C}-9), 147.6\left(\mathrm{C}-4^{\prime}\right)$, 147.2 (C-3'), 147.2 (C-4), 144.6 (C-3), 137.0 (C-7), 130.6 (C-1'), 127.2 (C-1), 123.5 (C-8), 120.8 (C-6'), 120.2 (C-6), $114.8\left(\mathrm{C}-5^{\prime}\right), 114.5(\mathrm{C}-5), 112.6\left(\mathrm{C}-2^{\prime}\right), 112.0(\mathrm{C}-2), 55.0$ $\left(3-\mathrm{OCH}_{3}\right), 54.9\left(3^{\prime}-\mathrm{OCH}_{3}\right), 41.0\left(\mathrm{C}-7^{\prime}\right), 34.7\left(\mathrm{C}-8^{\prime}\right)$.

\section{N-Trans-feruloyl-3'-methoxytyramine (9)}

Brown powder. ESI-MS ion peaks at $m / z 344.2[\mathrm{M}+\mathrm{H}]^{+}$ and $342.0[\mathrm{M}-\mathrm{H}]^{-} .{ }^{1} \mathrm{H} N M R$ data in $\mathrm{CD}_{3} \mathrm{OD}(600 \mathrm{MHz})$ : $\delta_{\mathrm{H}} 7.41(1 \mathrm{H}, d, J=15.6, \mathrm{H}-7), 7.09(1 \mathrm{H}, d, J=1.8, \mathrm{H}-2)$, $7.00(1 \mathrm{H}, d, J=8.4, \mathrm{H}-6), 6.79\left(1 \mathrm{H}, d, J=1.8, \mathrm{H}-2^{\prime}\right), 6.77$ $(1 \mathrm{H}, d, J=8.4, \mathrm{H}-5), 6.70\left(1 \mathrm{H}, d, J=8.4, \mathrm{H}-5^{\prime}\right), 6.64(1 \mathrm{H}$, $\left.d d, J=8.4,1.8, \mathrm{H}-6^{\prime}\right), 6.38(1 \mathrm{H}, d, J=15.6, \mathrm{H}-8), 3.86(3 \mathrm{H}$, $\left.\mathrm{s}, 3-\mathrm{OCH}_{3}\right), 3.81\left(3 \mathrm{H}, \mathrm{s}, 3^{\prime}-\mathrm{OCH}_{3}\right), 3.46(2 \mathrm{H}, t, J=7.2$, $\mathrm{H}-7 \alpha^{\prime}$ and $\left.\mathrm{H}-7 \beta^{\prime}\right), 2.74\left(2 \mathrm{H}, t, J=7.2, \mathrm{H}-8 \alpha^{\prime}\right.$ and $\left.\mathrm{H}-8 \beta^{\prime}\right)$. ${ }^{13} \mathrm{C}$ NMR data in $\mathrm{CD}_{3} \mathrm{OD}(600 \mathrm{MHz}): \delta_{\mathrm{C}} 167.8(\mathrm{C}-9)$, 148.5 (C-4'), 147.9 (C-3'), 147.6 (C-4), 144.7 (C-3), 140.7 (C-7), 130.7 (C-1'), 126.9 (C-1), 121.8 (C-8), 120.9 (C-6'), 117.4 (C-6), 115.1 (C-5'), 114.9 (C-5), 112.1 (C-2'), 110.2 
(C-2), $55.1\left(3-\mathrm{OCH}_{3}\right), 55.0\left(3^{\prime}-\mathrm{OCH}_{3}\right), 41.2\left(\mathrm{C}-7^{\prime}\right), 34.9$ $\left(\mathrm{C}-8^{\prime}\right)$.

\section{Trans-decursidate (10)}

Green powder. HRESI-MS ion peaks at $m / z 329.1028$ $[\mathrm{M}+\mathrm{H}]^{+} .{ }^{1} \mathrm{H}$ NMR data in $\mathrm{CD}_{3} \mathrm{OD}(600 \mathrm{MHz}): \delta \mathrm{H} 7.60$ $(1 \mathrm{H}, d, J=15.6, \mathrm{H}-7), 7.22\left(2 \mathrm{H}, d, J=9.0, \mathrm{H}-2^{\prime}\right.$ and $\left.\mathrm{H}-6^{\prime}\right)$, $7.14(1 \mathrm{H}, d, J=1.8, \mathrm{H}-6), 7.03(1 \mathrm{H}, d d, J=8.4,1.8, \mathrm{H}-2)$, $6.78(1 \mathrm{H}, d, J=11.4, \mathrm{H}-3), 6.76\left(2 \mathrm{H}, d, J=9.0, \mathrm{H}-3^{\prime}\right.$ and $\left.\mathrm{H}-5^{\prime}\right), 6.34(1 \mathrm{H}, d, J=15.6, \mathrm{H}-8), 4.79\left(1 \mathrm{H}, m, \mathrm{H}-8^{\prime}\right), 4.21$ $\left(2 \mathrm{H}, m, \mathrm{H}-7 \alpha^{\prime}\right.$ and $\left.\mathrm{H}-7 \beta^{\prime}\right), 3.84\left(3 \mathrm{H}, \mathrm{s}, 3-\mathrm{OCH}_{3}\right) .{ }^{13} \mathrm{C}$ NMR data in $\mathrm{CD}_{3} \mathrm{OD}(600 \mathrm{MHz}): \delta \mathrm{C} 169.2(\mathrm{C}-9), 158.4$ (C-4'), 150.7 (C-4), 149.4 (C-3), 147.1 (C-7), $133.2\left(\mathrm{C}-1^{\prime}\right)$, $128.8\left(\mathrm{C}-2^{\prime}\right.$ and $\left.\mathrm{C}-6^{\prime}\right), 127.8(\mathrm{C}-1), 124.2$ (C-6), 116.6

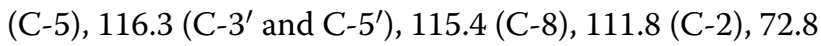
$\left(\mathrm{C}-8^{\prime}\right), 70.2\left(\mathrm{C}-7^{\prime}\right), 56.6\left(3-\mathrm{OCH}_{3}\right)$.

\section{Cis-decursidate (11)}

HRESI-MS ion peaks at $m / z$ 329.1028 $[\mathrm{M}+\mathrm{H}]^{+} .{ }^{1} \mathrm{H}$ NMR data in $\mathrm{CD}_{3} \mathrm{OD}(600 \mathrm{MHz}): \delta \mathrm{H} 7.72(1 \mathrm{H}, \mathrm{s}, \mathrm{H}-2)$. $7.19\left(2 \mathrm{H}, d, J=8.4, \mathrm{H}-2^{\prime}\right.$ and $\left.\mathrm{H}-6^{\prime}\right), 7.07(1 \mathrm{H}, d, J=8.4$, $\mathrm{H}-6), 6.83(1 \mathrm{H}, d, J=12.6, \mathrm{H}-7), 6.74\left(3 \mathrm{H}, m, \mathrm{H}-3, \mathrm{H}-3^{\prime}\right.$ and $\left.\mathrm{H}-5^{\prime}\right), 5.79(1 \mathrm{H}, d, J=12.6, \mathrm{H}-8), 4.79\left(1 \mathrm{H}, m, \mathrm{H}-8^{\prime}\right)$, $4.17\left(2 \mathrm{H}, m, \mathrm{H}-7 \alpha^{\prime}\right.$ and $\left.\mathrm{H}-7 \beta^{\prime}\right), 3.83\left(3 \mathrm{H}, \mathrm{s}, 3-\mathrm{OCH}_{3}\right) .{ }^{13} \mathrm{C}$ NMR data in $\mathrm{CD}_{3} \mathrm{OD}(600 \mathrm{MHz}): \delta \mathrm{C} 166.7$ (C-9), 156.9 (C-4'), 148.2 (C-4), 147.0 (C-3), 144.2 (C-7), $131.8\left(\mathrm{C}-1^{\prime}\right)$, $127.3\left(\mathrm{C}-2^{\prime}\right.$ and $\left.\mathrm{C}^{-6} 6^{\prime}\right), 126.8$ (C-1), 125.4 (C-6), 114.3 (C-5), 114.8 (C-3' and C-5'), 115.1 (C-8), 113.7 (C-2), 71.3 $\left(\mathrm{C}-8^{\prime}\right), 68.5\left(\mathrm{C}-7^{\prime}\right), 55.1\left(3-\mathrm{OCH}_{3}\right)$.

\section{4-Hydroxyphenylglycol (12)}

Brown oil. ESI-MS ion peaks at $m / z 155.2[\mathrm{M}+\mathrm{H}]^{+}$and 153.2 $[\mathrm{M}-\mathrm{H}]^{-} .{ }^{1} \mathrm{H}$ NMR data in $\mathrm{CD}_{3} \mathrm{OD}(600 \mathrm{MHz}): \delta_{\mathrm{H}}$ $7.16(2 \mathrm{H}, d, J=11.4, \mathrm{H}-3$ and $\mathrm{H}-5), 6.73(2 \mathrm{H}, d, J=11.4$, $\mathrm{H}-2$ and $\mathrm{H}-6), 4.56(1 \mathrm{H}, t, J=7.2, \mathrm{H}-8), 3.55(2 \mathrm{H}, d$, $J=7.2, \mathrm{H}-7) .{ }^{13} \mathrm{C}$ NMR data in $\mathrm{CD}_{3} \mathrm{OD}(600 \mathrm{MHz}): \delta_{\mathrm{C}}$ 156.6 (C-1), 132.7 (C-4), 127.3 (C-3 and C-5), 114.7 (C-2 and C-6), 74.4 (C-8), 67.4 (C-7).

\section{Preparation of standards and samples for HPLC analysis}

For HPLC analysis, the four dried samples $(100 \mathrm{mg})$ from different locations were extracted twice with $10 \mathrm{~mL}$ of $\mathrm{MeOH}$ for $10 \mathrm{~min}$ under ultrasonication. Afterwards, the mixtures were centrifuged at $4000 \mathrm{~g}$ for $10 \mathrm{~min}$, and each supernatant was passed through a disposable syringe filter $(0.22 \mu \mathrm{m}, 25 \mathrm{~mm}, \mathrm{CA}$ syringe fitter $)$ obtained from Futecs Co., LTD (Daejeon, Korea) and injected into the HPLC system. The chromatographic peaks from the sample solution were identified by comparing the retention times and UV spectra of the target compounds with those of standards.

Standards of $N$-trans-coumaroyltyramine (5), $\mathrm{N}$-cisferuloyltyramine (6), N-trans-feruloyltyramine (7),
$N$-cis-feruloyl-3'-methoxytyramine (8), N-transferuloyl-3'-methoxytyramine (9), Trans-decursidate (10), and Cis-decursidate (11) with over 98\% purity were obtained from ChemFaces (Wuhan, China). Solutions of seven compounds were prepared at concentrations of $5 \mathrm{mg} / \mathrm{mL}$ in $\mathrm{MeOH}$, and these stock solutions were stored at $+4{ }^{\circ} \mathrm{C}$ in a dark room. Moreover, serial dilution with $\mathrm{MeOH}$ was used to obtain solutions at fifteen concentrations $(0.01$ to $250 \mu \mathrm{g} / \mathrm{mL})$, and these solutions were used as the working solutions for HPLC analysis.

\section{Validation of the developed analysis method}

The HPLC analysis method developed herein to detect and quantify the three reference compounds from the samples was tested for linearity, accuracy, precision, LOD and LOQ based on the International Conference on Harmonization $(\mathrm{ICH})$ guidelines. The linearity was determined by calculating the value of $r^{2}$ (correlation coefficient) for the calibration curve prepared from fifteen serial concentrations. The precision was evaluated by the intermediate examination method by measuring the intra- and interday variability. The intraday variability was estimated by analyzing the sample solution on one of the study days $(24 \mathrm{~h})$, and the interday variability was determined by injecting the sample solutions on three different days. To determine the precision, RSD values were compared for the peak areas and retention times from five experiments. Moreover, to evaluate the accuracy, recovery tests were performed by spiking a samples with each standard compound at three different concentrations, and the recovery rates were determined by calculating the mean recovery (\%) of the standards from the spiked extract solutions vs. the nonspiked extract solutions. The LOD and LOQ were calculated by the signal-to-noise ratio $(\mathrm{S} / \mathrm{N})$ method, in which an $\mathrm{S} / \mathrm{N}$ ratio of 3 is used for the LOD, and an $\mathrm{S} / \mathrm{N}$ ratio of 10 is used for the LOQ.

\section{Conversion testing of the geometric isomers by UV-lights}

The geometric isomers (7, 9, and 10), which were identified as trans-forms were dissolved in $\mathrm{MeOH}$ to a concentration as $0.14(7), 0.1(9)$, and $0.07 \mathrm{mg} / \mathrm{mL}$ (10). The sample of Gyeong san was prepared with same sample preparation method for HPLC analysis. The three standards mixture and sample solutions were exposed under the UV lamp (30 W, UV output $13.4 \mathrm{~W}$, $253.7 \mathrm{~nm}$ ) in a dark room for $96 \mathrm{~h}$ for converting the cis and trans-isomers. After that, the fully converted standards mixture and a sample solution has been taken for HPLC analysis. 


\section{Result and discussion}

\section{Structure elucidation of the isolated compounds}

A total of 12 compounds (1-12) were isolated and identified following repeated separations by silica gel and ODS gel column chromatography of the EtOAc fraction of the $70 \%$ ethanol extract of Chongbaek. In these cases, except for 4, 10 and 11, all the compounds, namely, the other three coumaran derivatives ( $\mathbf{1}$ to $\mathbf{3}$ ), five cinnamic acid amides (5 to 9), and one hydroxy phenol (12), were determined by comparing their spectroscopic data with those previously reported in the literature. The compounds were identified as 2-hydroxy-1-(2-hydroxyphenyl)ethanone (1) [14], 3-methoxy-coumaran (2) [15, 16], coumaran (3) [15, 16], (1-(2-ethoxyphenyl)-1,2-ethanediol) (4) $[15,16], N$-trans-coumaroyltyramine (5) [12, 13], $N$-cis-feruloyltyramine (6) [13, 17], N-trans-feruloyltyramine (7) [17], N-cis-feruloyl-3'-methoxytyramine (8) [13, 17], N-trans-feruloyl-3'-methoxytyramine (9) [13, 17], trans-decursidate (10) [18-20], cis-decursidate (11) [18-20], and 4-hydroxyphenylglycol (12) [21].

\section{Optimization of analytical conditions and quantitation}

In this study, 12 compounds (1-12) were isolated for the standardization of Chongbaek. In addition, the chemical properties of the isolated compounds were considered when selecting standard compounds for HPLC/UV analysis. Of the isolated compounds, coumaran and its derivatives (1-4) are nonpolar, and the fact that they are oils makes them unsuitable for the analysis of water-extracted samples. In particular, GC/FID or MS are more suitable for the analysis of volatile compounds [22]. Additionally, coumaran (3) has not been reported in Chongbaek until now, but sulfur-containing compounds were shown by GC/MS to be present in the essential oil of a similar plant, Allium sphaerocephalon L. subsp. [23]. Moreover, cinnamic acid amides, including $N$-p-trans-coumaroyl tyramine (5) and $N$-trans-feruloyltyramine (7), have been shown to be abundant in A. fistulosum, with contents of 13.85 (5) and $1.99 \mu \mathrm{g} / \mathrm{g}(7)$, respectively; these contents are notably higher than their contents in other vegetables, such as tomato $(1.47 \mu \mathrm{g} / \mathrm{g}(5))$ and cherry tomato $(2.76 \mu \mathrm{g} / \mathrm{g}(5))$, as indicated by HPLC analysis in previous reports [24]. Compounds 5 and 7 were also found in 35 species of Allium species by HPLC-HRMS-SPE and NMR analyses, indicating that these compounds are not specific to Chongbaek [25]. Compound 9, which is structurally similar to 7 but possesses a methoxy groups at position $3^{\prime}$, has been reported from the Chongbaek [13] and Allium tripedale [26], but it has not been quantified in these raw materials. Compound $\mathbf{1 0}$ was reported for the first time from Peucedanum decursivum root [27], but it has also been isolated from Angelica purpuraefolia and root of Angelica sinensis [18, 28]. As with 11, although compound 10 has been previously identified from other plants, it has not been quantified. Therefore, it is not clear whether these compounds are specific to separate plants. If in practice, compounds $\mathbf{1 0}$ or $\mathbf{1 1}$ have relatively good specificity and can be used to differentiate Chongbaek, they may be ideal compounds for standardization studies. Finally, based on the above information, compounds 5-11 were selected as analysis standards for standardizing Chongbaek using HPLC/UV, and these compounds are cinnamic acid amides and decursidates.

Based on our optimization of the analysis conditions for the selected compounds, a gradient mixture of distilled water (A) and acetonitrile (B) was used because was found to be the most suitable. On the other hand, although the use of an acid buffer generally improves the separation of compounds, our preliminary results using formic, acetic or phosphoric acid as additive showed that the resolution of the trans compounds $(5,7$, 9, and 10) did not differ relative to the chromatograms obtained without buffer, and the peaks of the cis compounds were poorly resolved. The UV wavelength for analysis was optimized based on the UV absorbance of each compound, and $317 \mathrm{~nm}$ was selected as the optimal wavelength at which all seven compounds could be detected. For column selection, Triart C18 ExRS, which is a more hydrophobic resin than normal $\mathrm{C} 18$, was used to efficiently separate the polar compounds in the samples relatively quickly. Using the selected column, gradient elution with $\mathrm{A} / \mathrm{B}=85 / 15$ to $80 / 20(0-17 \mathrm{~min}), 80 / 20$ (17-22 $\mathrm{min}$ ), 80/20 to 74/26 (22-40 $\mathrm{min}$ ), and 74/26 (40$45 \mathrm{~min}$ ) at a flow rate of $1 \mathrm{~mL} / \mathrm{min}$ and oven temperature at $40{ }^{\circ} \mathrm{C}$ successfully resolved all the standards without interference from the matrix. Under these conditions, the retention times of the seven standard peaks were 25.2 (6), 28.2 (8), 30.3 (5), 33.6 (7), 36.2 (9), 36.8 (11), and 39.7 (10) $\min$ (Fig. 2).

Based on the analysis conditions optimized above, the contents of these compounds in Chongbaek samples which produced in four different regions (Jindo, Fig. 2c; Kimpo, Fig. 2d; and Yeongcheon, Fig. 2e) were compared, as were the samples used in the isolation of the compounds from Chongbaek (Gyeongsan; Fig. 2b). The analysis results confirmed that none of the cis derivatives were detectable in any of the samples and that only the trans isomers were observed. Of these Chongbaek samples from different regions (Fig. 2b-e), the same species showed very similar patterns in their HPLC/UV chromatograms; the contents of the compounds detected in the Gyeongsan sample were $7.9873 \pm 0.0183(5), 24.0126 \pm 0.1603$ (7), $5.7730 \pm 0.0381$ (9), and $8.6818 \pm 0.0544 \mu \mathrm{g} / \mathrm{g}$ (10) (Table 1 ), and the relative standard deviation (RSDs) 


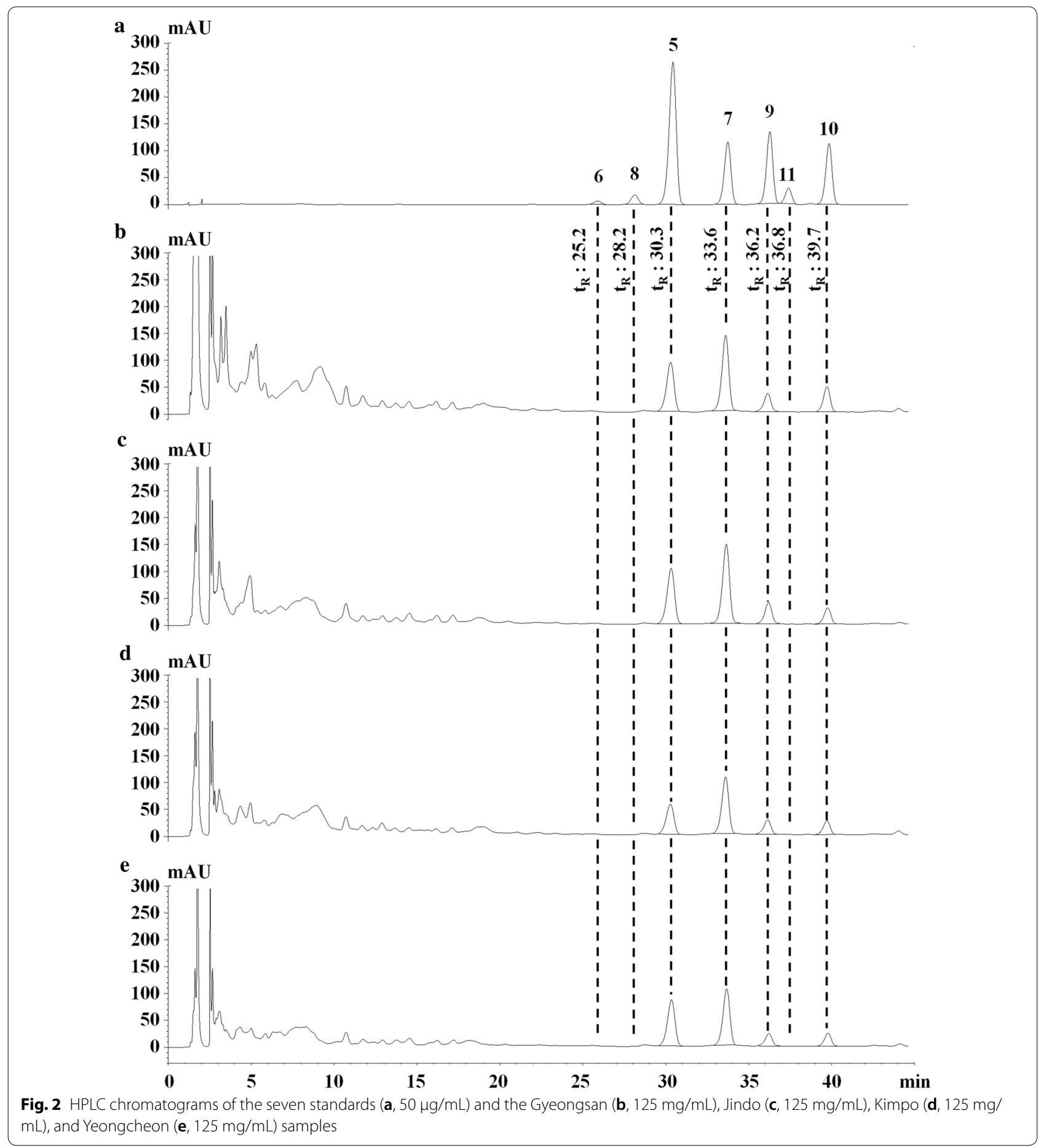

(\%) values compared to the compounds detected in the remaining three samples (Jindo, Kimpo, and Yeongcheon) were calculated as 17.9 (5), 17.6 (7), 21.0 (9), and $29.0 \%(10)$. As such, the similar quantitation values indicated that the use of the selected compounds as a standard is suitable for monitoring Chongbaek during commercial production and for the standardization of Chongbaek (Table 1).

On the other hand, from the quantitative analysis results of Chongbaek samples, and with the identified 
Table 1 Contents of the target compounds in the four different regions $(\mu \mathrm{g} / \mathrm{g})$

\begin{tabular}{lllll}
\hline Compound & \multicolumn{2}{l}{ Content $(\boldsymbol{n}=\mathbf{3})$} & & Kimpo \\
\cline { 2 - 5 } & Gyeongsan & Jindo & N.D. & Yeongcheon \\
\hline $\mathbf{6}$ & N.D. & N.D. & N.D. & N.D. \\
$\mathbf{8}$ & N.D. & N.D. & $5.7524 \pm 0.0288$ & N.D. \\
$\mathbf{5}$ & $7.9873 \pm 0.0183^{b}$ & $8.9920 \pm 0.0818$ & $7.6095 \pm 0.0203$ \\
$\mathbf{7}$ & $24.0126 \pm 0.1603$ & $25.8226 \pm 0.2104$ & $18.4636 \pm 0.0617$ & $18.4019 \pm 0.0730$ \\
$\mathbf{9}$ & $5.7730 \pm 0.0381$ & $6.8215 \pm 0.0865$ & $4.8845 \pm 0.0449$ & $4.1933 \pm 0.0201$ \\
$\mathbf{1 1}$ & N.D. & N.D. & N.D. & N.D. \\
$\mathbf{1 0}$ & $8.6818 \pm 0.0544$ & $5.9213 \pm 0.0452$ & $5.1054 \pm 0.0057$ & $4.7787 \pm 0.0191$ \\
\hline
\end{tabular}

$a$ Not detected

${ }^{b}$ Standard error $(\mu \mathrm{g} / \mathrm{g})$

compounds, which were obtained from isolation process in this study, we were able to discover the impressive and important phenomenon. All cis-types compounds were not detected in the all four analysis samples, however, during the separation process, they were isolated in a certain amount or more (2: 4.8, 4: 10.2, and 7: $31.3 \mathrm{mg}$ ). It implies the cis- were not the nature components. According to a previous report, these geometric isomers can interconvert upon exposure to UV light [17]. Meanwhile, in this case was the cinnamic acid amides were separated from other plants, but it was not clear whether these cis- were originally contained from raw materials or biosynthetic produced during the separation process. Also, at least until recently, the reports of cis-type cinnamic acid amides separated from the Chongbaek could only confirm one case [13]. Therefore, in order to clearly verify these phenomena, using the newly developed analysis method, the conversion study of the sample and these geometric isomers was carried out as follows.

\section{Conversion study of the geometric isomers}

As described above, the conversions of cis- and transferuloyltyramine and feruloyl-3'-methoxytyramine under UV light exposure have been reported previously [17]. Therefore, isolated compounds 6-9 were expected to undergo structural conversion upon exposure to UV light. On the other hand, compounds 10 and 11, in which the nitrogen was replaced by an oxygen, have not been shown to undergo structural conversion. Additionally, these structural conversions by UV light should be verified because they could have unexpected effects on the stability and quality of the standardization materials used for quality control. Therefore, this study investigated the structural conversions of compound 6-11 using the same conditions used in the previously reported conversion
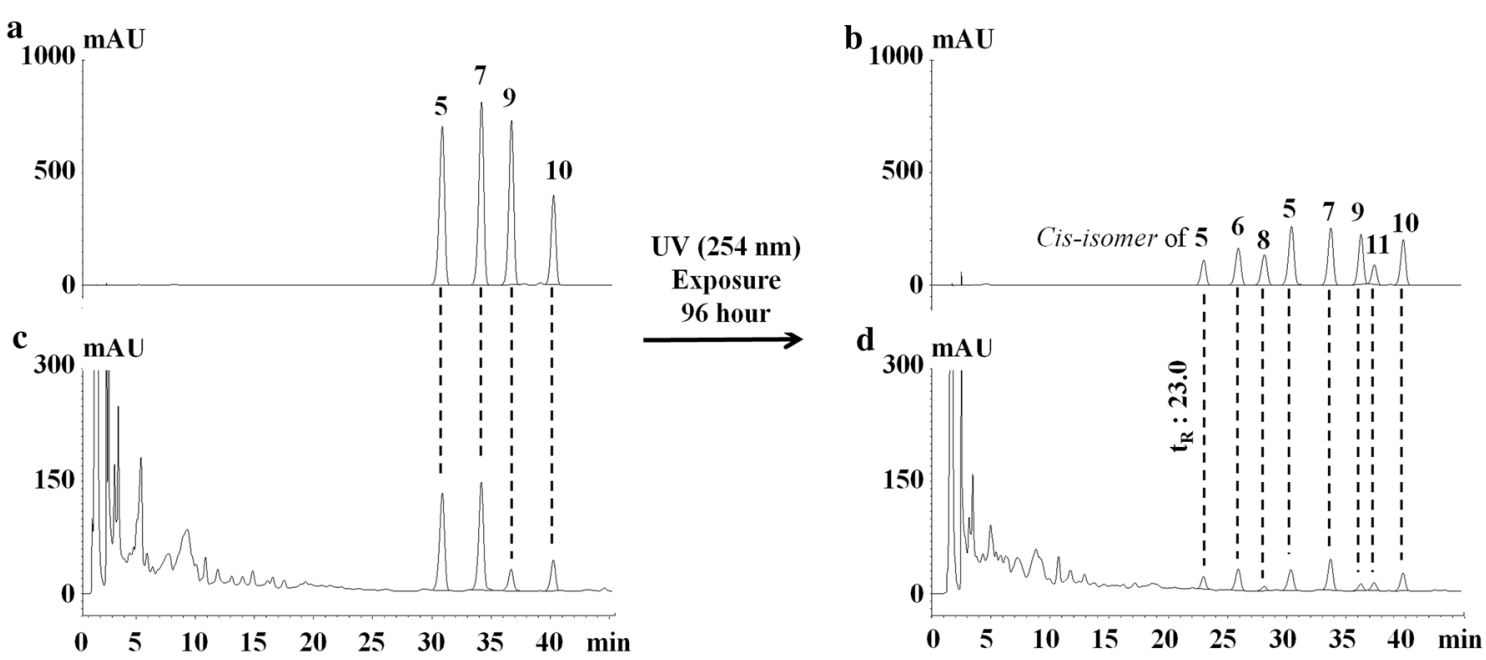

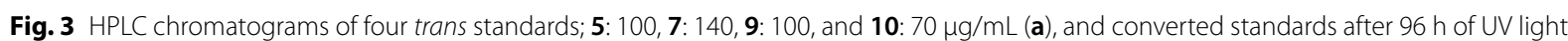
$(254 \mathrm{~nm})$ exposure (b) The Gyeong san sample before UV exposure (c, $125 \mathrm{mg} / \mathrm{mL})$, and the sample after $96 \mathrm{~h}$ of UV (254 nm) exposure (d) 
Table 2 Content and conversion ratios of converted compounds in standard mixtures and Gyeongsan samples $(\mu \mathrm{g} / \mathrm{g})$

\begin{tabular}{|c|c|c|c|c|}
\hline Compound & $\begin{array}{l}\text { Standard contents }(n=3) \\
\text { and ratio }\end{array}$ & $\begin{array}{l}\text { Standard converted contents } \\
(\mu \mathrm{g} / \mathrm{g}) \text { and ratio }\end{array}$ & $\begin{array}{l}\text { Sample contents }(\mu \mathrm{g} / \mathrm{g}) \\
\text { and ratio }\end{array}$ & $\begin{array}{l}\text { Sample converted } \\
\text { contents }(\mu \mathrm{g} / \mathrm{g}) \\
\text { and ratio }\end{array}$ \\
\hline 6(cis) & N.D ${ }^{a}(0 \%)$ & $108.97 \pm 0.01^{b}(78.74 \%)$ & N.D (0\%) & $19.78 \pm 0.02(82.38 \%)$ \\
\hline 7 (trans) & $138.39 \pm 0.39(100 \%)$ & $32.17 \pm 0.17(23.25 \%)$ & $24.01 \pm 0.16(100 \%)$ & $3.67 \pm 0.04(15.29 \%)$ \\
\hline $8(c i s)$ & N.D $(0 \%)$ & $83.38 \pm 0.13$ (82.29\%) & N.D $(0 \%)$ & $3.63 \pm 0.04(62.91 \%)$ \\
\hline 9 (trans) & $101.33 \pm 0.05(100 \%)$ & $17.54 \pm 0.03(17.31 \%)$ & $5.77 \pm 0.04(100 \%)$ & $1.36 \pm 0.09(23.57 \%)$ \\
\hline 11 (cis) & N.D $(0 \%)$ & $45.01 \pm 0.09$ (63.99\%) & N.D $(0 \%)$ & $5.35 \pm 0.03(61.64 \%)$ \\
\hline 10 (trans) & $70.34 \pm 0.03(100 \%)$ & $25.99 \pm 0.09$ (36.95\%) & $8.68 \pm 0.05(100 \%)$ & $3.31 \pm 0.06(38.13 \%)$ \\
\hline
\end{tabular}

a Not detected

b Standard error $(\mu \mathrm{g} / \mathrm{g})$

experiment. In addition, the compounds before and after conversion were quantified, which was not reported in the previous studies.

Before selecting the compounds to convert, the quantities of the analytes prior to UV light exposure were confirmed (Fig. 3c). None of the cis derivatives were detected in any of the samples, and the contents of the trans compounds were verified as $24.01 \pm 0.16$ (7), $5.77 \pm 0.04$ (9), and $8.68 \pm 0.05 \mu \mathrm{g} / \mathrm{g}(\mathbf{1 0})$ (Table 2). Therefore, in a typical environment, the only the trans geometric isomers were initially present. Notably, it was reported that upon exposure to UV light for $96 \mathrm{~h}$, the final stabilization ratios of feruloylamides varied slightly depending on the structure. Initially, compound 7 accounted for $23.6 \%$ of the mixture, and 9 accounted for $29.4 \%$. However, since these values are based on area ratios from the chromatogram acquired by HPLC/UV at $210 \mathrm{~nm}$, the absolute content ratio could not be determined. In particular, when this study examined the optimum absorbance of the cis and trans compounds for quantitative analysis, these compounds showed significantly different absorbance at $210 \mathrm{~nm}$. Thus, a conversion test was conducted under the same conditions, and the final stabilized ratio was quantified using the newly developed analysis method described above (Fig. 3b). The results of that quantification were slightly different from those of a previous report, and the contents of the cis and trans compounds in the samples exposed to UV light for $96 \mathrm{~h}$ were $19.78 \pm 0.02(\mathbf{6}), 3.67 \pm 0.04$ (7), $3.63 \pm 0.04$ (8), $1.36 \pm 0.09$ (9), $5.35 \pm 0.03(\mathbf{1 1})$, and $3.31 \pm 0.06 \mu \mathrm{g} / \mathrm{g}$ (10) (Table 2). These quantitative values were calculated as percentages, which were converted to the contents of the cis and trans compounds in the UV-exposed samples, and the content of the trans compound prior to UV exposure was taken as $100 \%$. The stabilized ratio, calculated as a percentage, for compound $7, \mathrm{~N}$-trans-feruloyltyramine, was $15.29 \%$, and that of its cis-form, $\mathbf{6}$, was $82.38 \%$. Compound 10, trans-decursidate, showed a stabilization ratio of $38.13 \%$, and compound 11 , gave a ratio of $61.64 \%$. The above results indicate that for compound $\mathbf{1 1}$, as well as all the other cis isomers in this report, the cis isomer is not present in the Chongbaek in its original state. For compound 9, $N$-trans-feruloyl- $3^{\prime}$-methoxytyramine, its stability ratio was calculated as $23.57 \%$, and $62.91 \%$ of that compound was converted to the cis isomer (8). Moreover, the combined content of converted compounds $\mathbf{8}$ and 9 was $4.99 \mu \mathrm{g} / \mathrm{g}$; because there was $5.77 \mu \mathrm{g} / \mathrm{g}$ of the trans compounds prior to UV exposure, only $86.48 \%$ of the material was now detectable (Table 2). We then confirmed the conversion rates of the pure trans standards to ensure that they were unaffected by other impurities in the sample during the conversion process. To determine the preconversion content in a standard, the standard mixtures were prepared at known concentrations (0.14 (7), 0.1 (9), and $0.07 \mathrm{mg} / \mathrm{mL}(\mathbf{1 0})$ ) (Fig. 3a), and the contents were verified by comparison with the obtained regression curve. The contents of each of the three standards in the mixture were calculated to be $138.39 \pm 0.39$ (7), $101.33 \pm 0.05$ (9), and $70.34 \pm 0.03 \mu \mathrm{g} / \mathrm{g}$ (10) (Table 2). As in the conversion tests, the samples were irradiated with UV light for $96 \mathrm{~h}$, and the converted contents of the cis and trans compounds were calculated as 6: $108.97 \pm 0.01$ (78.74\%), $7: 32.17 \pm 0.17$ (23.25\%), 8: $83.38 \pm 0.13(82.29 \%), 9: 17.54 \pm 0.03$ (17.31\%), 11: $45.01 \pm 0.09$ (63.99\%), and 10: $25.99 \pm 0.09 \mu \mathrm{g} / \mathrm{g}(36.95 \%)$ (Table 2). As such, the amounts of 8 (cis) and $\mathbf{9}$ (trans) generated by the conversion of 9 were different from the results of other tests. Compound 7 , which possessed one fewer methoxy group than 9, showed a slightly higher rate of cis conversion in the samples of $\mathbf{6}$ and 7. Moreover, the ratios of compounds $\mathbf{1 0}$ and $\mathbf{1 1}$ in the standards and in the samples were very similar, and no decrease in the combined content of the cis and trans isomers was observed. Thus, additional experiments on the phenomena that cause this difference in relation to the structure of compounds 7 and $\mathbf{9}$ are still needed, but we have 
Table 3 Linearity of the standard compounds

\begin{tabular}{|c|c|c|c|}
\hline Compound & $\begin{array}{l}\text { Linear } \\
\text { range (mg/ } \\
\mathrm{mL})\end{array}$ & Equation (Linear Model) $^{a}$ & $r^{2 b}$ \\
\hline 6 & $0.5 \sim 250$ & $y=3944,173.7224 x-1,709.1736$ & 0.99 \\
\hline 8 & $0.5 \sim 250$ & $y=11,017,616.0029 x-2,980.1769$ & 0.99 \\
\hline 5 & $0.5 \sim 250$ & $y=211,094,925.7100 x-57,044.7096$ & 0.99 \\
\hline 7 & $0.5 \sim 250$ & $y=69,477,806.3079 x-101,916.6673$ & 0.99 \\
\hline 9 & $0.5 \sim 250$ & $y=75,497,890.9180 x-108,147.5971$ & 0.99 \\
\hline 11 & $0.5 \sim 250$ & $y=15,934,690.0903 x-20,174.2768$ & 0.99 \\
\hline 10 & $0.5 \sim 250$ & $y=67,917,403.3750 x-95,185.9719$ & 0.99 \\
\hline
\end{tabular}

carefully assumed that the influence on the decomposition by UV light is from the additional methoxy group.

Trans compound 5 ( $N$-p-trans-coumaroyltyramine), which eluted at $30.3 \mathrm{~min}$, as shown in Fig. 3, was also treated with 7, 9, and 10 and subjected to a conversion study. Unfortunately, its cis isomer was not isolated from this study, nor is it commercially available for use as a standard. Therefore, the exact conversion rate was not verified. However, the peak detected in $23.0 \mathrm{~min}$ in the chromatogram indicated that it underwent conversion by UV light similar to other trans compounds.

\section{Assay validation}

The linearity was confirmed with a total of eleven sequentially diluted solutions at concentrations from 0.5 to $250 \mu \mathrm{g} / \mathrm{mL}$ with three replicates for each standard. Each calibration curve showed good linearity with correlation coefficients ( $r^{2}$ value) above 0.99 . (Table 3 ).

The accuracy and precision were determined by spiking standard solutions with three different concentrations $(2.5,5$, and $10 \mu \mathrm{g} / \mathrm{mL})$ of the Gyeong san sample to calculate the recovery and relative standard deviation (RSD) values. The recoveries (\%), which indicates accuracy, ranged from 96.00 to $106.72 \%$ for $\mathbf{6}, 96.46$ to $100.78 \%$ for $\mathbf{8}, 99.36$ to $106.44 \%$ for $\mathbf{5}, 96.30$ to $104.17 \%$ for $7,99.38$ to $102.21 \%$ for $\mathbf{9}, 95.70$ to $103.07 \%$ for $\mathbf{1 1}$, and 97.51 to $101.65 \%$ for $\mathbf{1 0}$ for both inter- and intraday experiments. The precision was determined from each RSD value derived from the inter- and intraday experiments, and for compounds $6,8,5,7,9,11$, and 10, and precisions ranged from 0.21 to $2.58 \%, 0.40$ to $1.85 \%, 0.24$ to $1.83 \%, 0.43$ to $1.93 \%, 0.61$ to $1.60 \%, 0.29$ to $1.33 \%$, and 0.34 to $1.82 \%$, respectively. Therefore, the above results indicate sufficient accuracy and precision for all seven of the target compounds present in the Chongbaek samples (Table 4).
Table 4 Accuracy and intraday and interday precision of the standard compounds in Gyeongsan

\begin{tabular}{|c|c|c|c|c|c|}
\hline \multirow[t]{2}{*}{ Compound } & \multirow{2}{*}{$\begin{array}{l}\text { Spiked } \\
(\mu \mathrm{g} / \mathrm{mL})\end{array}$} & \multicolumn{2}{|l|}{ Interday } & \multicolumn{2}{|l|}{ Intraday } \\
\hline & & $\begin{array}{l}\text { Recovery } \\
(\%, n=3)\end{array}$ & $\operatorname{RSD}^{a}(\%)$ & $\begin{array}{l}\text { Recovery } \\
(\%, n=3)\end{array}$ & RSD (\%) \\
\hline \multirow[t]{3}{*}{6} & 2.5 & 96.00 & 2.58 & 97.77 & 2.53 \\
\hline & 5 & 105.46 & 0.21 & 103.51 & 1.88 \\
\hline & 10 & 106.72 & 0.85 & 104.40 & 1.53 \\
\hline \multirow[t]{3}{*}{8} & 2.5 & 98.97 & 0.51 & 98.10 & 1.21 \\
\hline & 5 & 96.46 & 1.85 & 96.96 & 1.59 \\
\hline & 10 & 96.47 & 0.40 & 100.78 & 1.08 \\
\hline \multirow[t]{4}{*}{5} & 2.5 & 100.50 & 1.61 & 99.36 & 1.83 \\
\hline & 5 & 106.44 & 1.16 & 102.66 & 0.24 \\
\hline & 10 & 101.60 & 0.25 & 101.97 & 0.84 \\
\hline & 2.5 & 96.40 & 1.61 & 97.86 & 1.93 \\
\hline \multirow[t]{3}{*}{7} & 5 & 104.17 & 1.50 & 96.30 & 0.43 \\
\hline & 10 & 100.87 & 0.70 & 100.65 & 0.51 \\
\hline & 2.5 & 100.84 & 1.07 & 100.80 & 1.14 \\
\hline \multirow[t]{3}{*}{9} & 5 & 102.21 & 1.60 & 101.64 & 1.47 \\
\hline & 10 & 99.38 & 1.39 & 100.07 & 0.61 \\
\hline & 2.5 & 96.50 & 1.33 & 95.70 & 0.29 \\
\hline \multirow[t]{3}{*}{11} & 5 & 102.94 & 1.09 & 103.07 & 1.19 \\
\hline & 10 & 98.27 & 0.47 & 98.97 & 0.98 \\
\hline & 2.5 & 99.81 & 1.24 & 101.65 & 1.38 \\
\hline \multirow[t]{2}{*}{10} & 5 & 100.36 & 1.82 & 97.51 & 0.88 \\
\hline & 10 & 99.15 & 0.34 & 97.95 & 1.40 \\
\hline
\end{tabular}

${ }^{a}$ RSD: relative standard deviation

The limits of detection (LODs) and limits of quantification (LOQs) were evaluated based on the average standard deviations (SD) value with eight replications from each of the nine low concentration standards $(0.02 \mu \mathrm{g} /$ $\mathrm{mL}$ ), which substituted on the five low-concentration regression curve $(0.01$ to $0.4 \mu \mathrm{g} / \mathrm{mL})$. And then, the LOD and LOQ values were calculated by multiplying the each of standards SD by 3.3, and 10, respectively. Based on this, the LODs were calculated to be 0.05 for $\mathbf{6}, 0.01$ for 8, 0.0005 for 5, 0.001 for 7, 0.001 for $\mathbf{9}, 0.003$ for $\mathbf{1 1}$, and $0.001 \mu \mathrm{g} / \mathrm{mL}$ for 10 . The LOQs were calculated by multiplying each LOD value by $10 / 3$, which resulted in the following LOQs: 6, 0.1667; 8, 0.333; 5, 0.0017; 7, 0.0033; 9, 0.0033; 11, 0.01; and 10, $0.0033 \mu \mathrm{g} / \mathrm{mL}$.

\section{Conclusions}

In this study, we identified new compounds that can replace the previously used reference standards and used these alternatives to develop a new analysis method for standardizing the Chongbaek. Twelve compounds were isolated and purified through various chromatographic techniques, and their structures were determined through NMR spectroscopy and MS 
techniques. Of the isolated compounds, the structure of cis- and trans-, decursidate, was reported for the first time in Chongbaek. Thus, considering the chemical properties of these identified compounds, the five cinnamic acid amides and their geometric isomers as well as cis- and trans decursidate were selected as marker compounds for Chongbaek standardization.

Later, for the standardization of materials that are essential for quality control, a comparative study on the content of standards were conducted by using four different regions products. The analysis of the contents of these compounds in four kinds of Chongbaek samples from different regions showed that the cis derivatives were never detected in the samples; however, the trans derivatives were present at concentrations of $5.7524 \pm 0.0288$ to $8.9920 \pm 0.0818$ (5), $18.4019 \pm 0.0730$ to $25.8226 \pm 0.2104$ (7), $4.1933 \pm 0.0201$ to $6.8215 \pm 0.0865$ (9), and $4.7787 \pm 0.0191$ to $8.6818 \pm 0.0544 \mu \mathrm{g} / \mathrm{g}(\mathbf{1 0})$ in the four kinds of Chongbaek samples. Additionally, the developed analysis method was validated based on linearity $\left(r^{2}>0.99\right)$, accuracy $(96.00-106.72 \%)$, precision $(<2.58 \%)$, LOD $(<0.05 \mu \mathrm{g} / \mathrm{g})$, and LOQ $(<0.1667 \mu \mathrm{g} / \mathrm{g})$. These also suggested that cis to trans interconversion was possible, and a conversion study involving one sample (Kung-san) and three trans standards $(7,9$ and 10) was conducted. Each of the three trans compounds in the sample was converted to its cis isomer at conversion of $82.38 \%(6)$, $62.91 \%(8)$, and $61.64 \%(11)$, and the conversions of pure trans standards were verified to confirm the conversion phenomena observed when the samples were exposed to UV light. It was confirmed that the trans derivatives were converted to their cis isomers at rates of $78.74 \%$ (6), $82.29 \%$ (8), and 63.99\% (11). Therefore, the cis compounds identified in Chongbaek samples are not present in the plant material in its normal, natural environment, and they are generated by the conversion of the trans isomers under UV light when in solution. In addition, although their stability limits their applicability as marker compounds for the standardization of raw materials, they remained stable during the validation of the sample preparation process and the analysis method developed in this study. Thus, the standardization of raw materials using these compounds is fully possible if the exposure to light can be controlled, making these compounds potential marker compounds for Chongbaek.

\section{Acknowledgements}

This work was supported by the INNOPOLIS Foundation of Korea (2019-DDRD-0044) and the National Research Council of Science \& Technology (NST) grant by the Korea government (MSIT) (No. CAP-16-07-KIOM).

\section{Authors' contributions}

JTH and BSK conceived of the idea presented. JTH, HJK and DHJ carried out the experiments and verified the analytical methods. JTH wrote the manuscript with input from all authors. JAR and BSK contributed to the interpretation of the results. All authors discussed the results and provide critical feedback to the final manuscript. All authors read and approved the final manuscript.

\section{Funding}

INNOPOLIS Foundation of Korea (2019-DD-RD-0044) and the National Research Council of Science \& Technology (NST) grant by the Korea government (MSIT) (No. CAP-16-07-KIOM).

\section{Availability of data and materials}

The datasets used and/or analyzed during the current study are available from the corresponding author on reasonable request.

\section{Competing interests}

The authors declare that they have no competing interests.

Received: 26 April 2020 Accepted: 30 June 2020

Published online: 13 July 2020

\section{References}

1. Sung Y, Kim S, Yoo BW, Kim HK (2015) The nutritional composition and anti-obesity effects of an herbal mixed extract containing Allium fistulosum and Viola mandshurica in high-fat-diet-induced obese mice. BMC Complement Altern Med. 15:370

2. Kim I (2014) The origin and daily dose of Allii Fistulosi bulbus in treatise on cold damage diseases. Kor J Herbol. 29(5):39-43

3. Fukaya M, Nakamura S, Nakagawa R, Kinka M, Nakashima S, Matsuda H (2019) Cyclic sulfur-containing compounds from Allium fistulosum 'Kujou'. J Nat Med 73:397-403

4. Ko B, Ryuk JA, Hwang JT, Zhang T, Wu X, Kim HJ, Yi QJ, Park S (2019) Allium fistulosum (Welsh onion) and Portulaca oleracea increase longitudinal bone growth in weanling rats possibly by promoting TGF- $\beta$ and IGF-1 signaling. J Funct Foods. 58:151-160

5. Marchese A, Barbieri R, Sanches-Silva A, Daglia M, Nabavi SF, Jafari NJ, Izadi M, Ajami M, Nabavi SM (2016) Antifungal and antibacterial activities of allicin: a review. Trends Food Sci Technol 52:49-56

6. Dubey H, Singh A, Patole AM, Tenpe CR (2017) Antihypertensive effect of allicin in dexamethasone-induced hypertensive rats. Integr Med Res. 6:60-65

7. Kim HW, Kim B, Kim Y, Ko S (2015) Development of extraction method for welsh onion root by alliinase activation. Food Eng. Prog. 19(2):117-121

8. Sung Y, Kim S, Kim D, Park SH, Yoo BW, Kim HK (2014) Nutritional composition and anti-obesity effects of cereal bar containing Allium fistulosum (welsh onion) extract. J Funct Foods. 6:428-437

9. Vlase L, Parvu M, Parvu EA, Toiu A (2013) Chemical constituents of three Allium species from Romania. Molecules 18:114-127

10. Zolfaghari B, Yazdiniapour Z, Sadeghi M, Troiano R, Lanzotti V (2016) Furostanol saponins from the bulbs of welsh onion Allium fistulosum L. Planta Med. 82(18):1584-1590

11. Zolfaghari B, Yazdiniapour Z, Sadeghi M, Akbari M, Troiano R, Lanzotti V. (2020) Cinnamic acid derivatives from welsh onion (Allium fistulosum) and their antibacterial and cytotoxic activities. Phytochem Anal. 1-7

12. Nishioka T, Watanabe J, Kawabata J, Niki R (1997) Isolation and activity of N-p-coumaroyltyramine, an (a-glucosidase inhibitor in welsh onion (Allium fistulosum). Biosci Biotech Biochem. 61 (7):1138-1141

13. Seo G, Cho J, Moon J, Park K (2011) Isolation and identification of cinnamic acid amides as antioxidants from Allium fistulosum $L$. and their free radical scavenging activity. Food Sci Biotechnol. 20:555

14. Vedhagiri S, Ackermann T, Ackermann L (2012) Ruthenium-catalyzed $\mathrm{C}-\mathrm{H}$ bond oxygenations with weakly coordinating ketones. Org. 14(24):6206-6209

15. Shaikh AK, Varvounis G (2014) Novel synthesis of 3-substituted 2,3-dihydrobenzofurans via ortho-quinone methide intermediates generated in situ. Org Lett 16:1478-1481

16. Rajashekar Y, Kumar HV, Ravindra K, Bakthavatsalam N (2013) Isolation and characterization of biofumigant from leaves of Lantana camara for control of stored grain insect pests. Ind Crops Prod 51:224-228

17. Hwang JT, Kim Y, Jang H, Oh H, Lim C, Lee SW, Rho M (2016) Study of the UV Light conversion of feruloyl amides from Portulaca oleracea and their inhibitory effect on IL-6-induced STAT3 activation. Molecules 21:865 
18. Lee H, Oh S, Kwon O, Ahn K, Lee J, Kim J, Min B, Joung H (2007) Isolation of coumarins and ferulate from the roots of Angelica purpuraefolia and the antitumor activity of khellactone. Phytother Res. 21:406-409

19. Zhang L, Lv J (2018) A new ferulic acid derivative and other anticoagulant compounds. Chem Nat Compd 54(1):13-17

20. Shu P, Li J, Fei Y, Zhu H, Yu M, Liu A, Niu H, Zou S, Wei X, Ju Z, Xu Z (2019) Isolation, structure elucidation, tyrosinase inhibitory, and antioxidant evaluation of the constituents from Angelica dahurica roots. J Nat Med 74:456-462

21. Ishikawa T, Kondo K, Kitajima J (2003) Water-soluble constituents of coriander. Chem Pharm Bull 51(1):32-39

22. Kuś PM, Jerković I, Tuberoso CIG, Šarolić M (2013) The volatile profiles of a rare apple (Malus domestica Borkh.) honey: shikimic acid-pathway derivatives, terpenes, and others. Chem Biodivers 10:1638-1652

23. Lazarević JS, Ethorđević AS, Zlatković BK, Radulović NS, Palić RM (2011) Chemical composition and antioxidant and antimicrobial activities of essential oil of Allium sphaerocephalon L. subsp. sphaerocephalon (Liliaceae) inflorescences. J Sci Food Agric. 91(2):322-329

24. Ly D, Kang K, Choi J, Ishihara A, Back K, Lee S (2008) HPLC analysis of serotonin, tryptamine, tyramine, and the hydroxycinnamic acid amides of serotonin and tyramine in food vegetables. J Med Food 11(2):385-389
25. Schmidt JS, Nyberg NT, Staerk D (2014) Assessment of constituents in Allium by multivariate data analysis, high-resolution a-glucosidase inhibition assay and HPLC-SPE NMR. Food Chem 161:192-198

26. Chehri Z, Zolfaghari B, Dinani MS (2018) Isolation of cinnamic acid derivatives from the bulbs of Allium tripedale. Adv Biomed Res. 7:60

27. Chen Y, Chen P, Wu C, Tsai I, Chen I (2008) Chemical constituents and antiplatelet aggregation activity from the root of Peucedanum formosanum. J Food Drug Anal. 16(3):15-25

28. Van NTH, Anh NTH, Sung TV, Frenke K, Wessjohann L (2004) Stilbene, ferulic acid and its derivatives from the roots of Angelica sinensis. Tạp chí Hóa hoc, T. 42(4):508-511

\section{Publisher's Note}

Springer Nature remains neutral with regard to jurisdictional claims in published maps and institutional affiliations.

\section{Submit your manuscript to a SpringerOpen ${ }^{\circ}$ journal and benefit from:}

- Convenient online submission

- Rigorous peer review

- Open access: articles freely available online

- High visibility within the field

- Retaining the copyright to your article

Submit your next manuscript at springeropen.com 